\title{
Trigeminal trophic syndrome following anterior inferior cerebellar artery infarction
}

\author{
Ummer Karadan, ${ }^{1}$ Robin George Manappallil, ${ }^{2}$ Anisha Janardhanan, ${ }^{3}$ \\ Ramesh Naga Supreeth²
}

${ }^{1}$ Department of Neurology, Baby Memorial Hospital, Calicut, India ${ }^{2}$ Department of Internal Medicine, Baby Memorial Hospital, Calicut, India ${ }^{3}$ Department of Dermatology, Baby Memorial Hospital, Calicut, India

\section{Correspondence to} Dr Robin George Manappallil, drrobingeorgempl@gmail.com

Accepted 12 April 2018

\section{DESCRIPTION}

A 70-year-old woman with hypertension presented about 3 months ago with complaints of dysarthria, left lower motor neuron facial palsy with preserved Bell's phenomenon, sensory loss over the left side of her face (V1, V2, V3) along with the left half of the tongue, absent left corneal and conjunctival reflexes, and gait ataxia. MRI of the brain showed an acute left anterior inferior cerebellar artery infarction (figure 1). She was treated with antiplatelets, statins and antihypertensives.

At present, she complained of 1-month history of multiple non-healing painless ulcers over the left side of her face below the nostril, and on the left side of the nose and forehead. Her left eye had undergone keratosis (figure 2). She had consulted local doctors, who prescribed her topical antibiotics and steroids, and eye-drops, but there was no improvement. There were no vesicles or peripheral nerve thickening. Her vitals were stable. Neurologically, she had left lower motor neuron facial palsy, difficulty in closing her left eye, sensory loss over the trigeminal area, diminished corneal and conjunctival reflexes, and left sensorineural hearing loss. She also had left-sided incoordination. Other systemic examinations were normal. Her blood

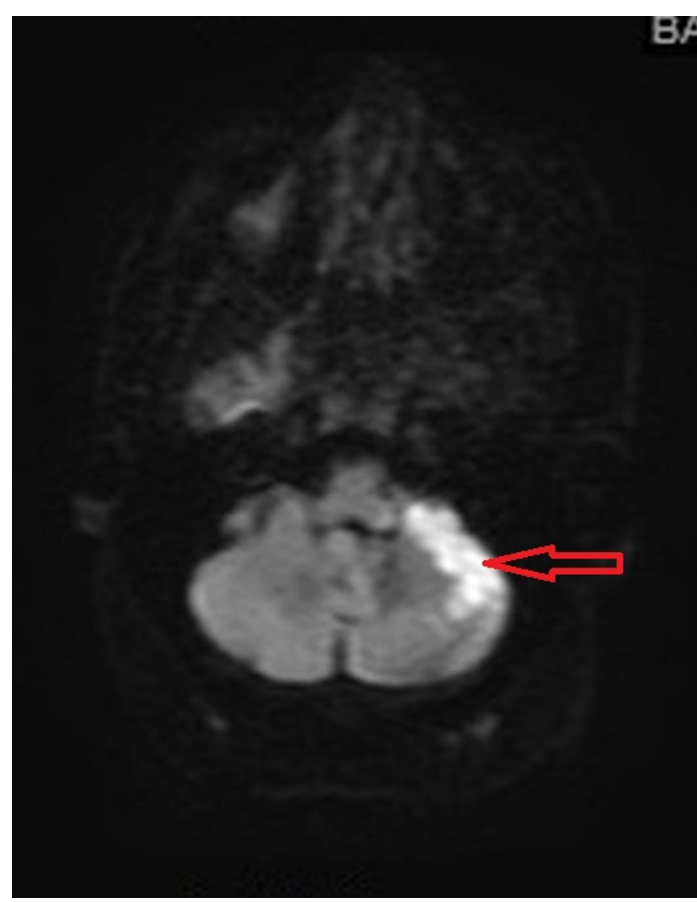

Figure $1 \mathrm{MRI}$ of the brain showing an acute infarct in the left anterior inferior cerebellar territory. investigations such as complete blood count, renal and liver functions, electrolytes, thyroid-stimulating hormone and haemoglobin A1c were normal. Her lipid profile showed mild dyslipidaemia. Viral markers (HIV, HBsAg, anti-HCV), VDRL and ANA profile were negative. Skin smear for bacteria and acid-fast bacilli were also negative.

On further probing, she revealed repeated scratching of the left side of her face due to an itching sensation following the stroke event. From the history and clinical findings, a diagnosis of trigeminal trophic syndrome was considered. She was treated with topical antibiotics (clindamycin) and saline dressings, and antibiotic eye-drops (ciprofloxacin). Antiplatelets (aspirin $75 \mathrm{mg}$ and clopidogrel $75 \mathrm{mg}$ once daily), antihypertensives (telmisartan $40 \mathrm{mg}$ once daily) and statins (rosuvastatin $5 \mathrm{mg}$ once daily) were continued. She was counselled regarding scratching of the left side of her face. She was also advised left eye keratoplasty, but was not willing. Botox injection was given as a therapeutic treatment for the partial ptosis of the left eyelid. She was asked to return after 1 week, but was lost to follow-up.

Cerebrovascular accidents involving the anterior inferior cerebellar artery are characterised by ipsilateral cerebellar ataxia, Horner's syndrome, involvement of V, VII and VIII cranial nerves, and contralateral sensory disturbance of temperature sensation. An occlusion of the internal auditory artery can result in peripheral vestibular syndrome. ${ }^{1-4}$ Trigeminal trophic syndrome is a rare condition that occurs following damage to the trigeminal nerve or its central sensory connection. It was first described by Loveman ${ }^{5}$ and McKenzie ${ }^{6}$ in 1933, and is characterised by painless persistent ulceration of the ala nasi. These lesions may also occur in the corners of the eyes, scalp or the inside of the mouth. The tip of the nose is spared as it derives sensation from the medial branch of the anterior ethmoidal nerve. It is more common among women. It may be idiopathic or may follow trigeminal nerve ablation, Wallenberg syndrome, amyloid deposition in the central nervous system and trigeminal nerve, trauma, craniotomy, herpes zoster, herpes simplex, leprosy, syphilis, birth trauma, or as postencephalitic sequelae. ${ }^{78}$ The manifestations of trigeminal trophic syndrome begin weeks to years after the injury to the trigeminal nerve, with an average of 2 years. These patients usually complain of picking, rubbing or scratching sensations over the affected areas, and the ulceration is unknowingly self-induced due to repeated touching of the face and 


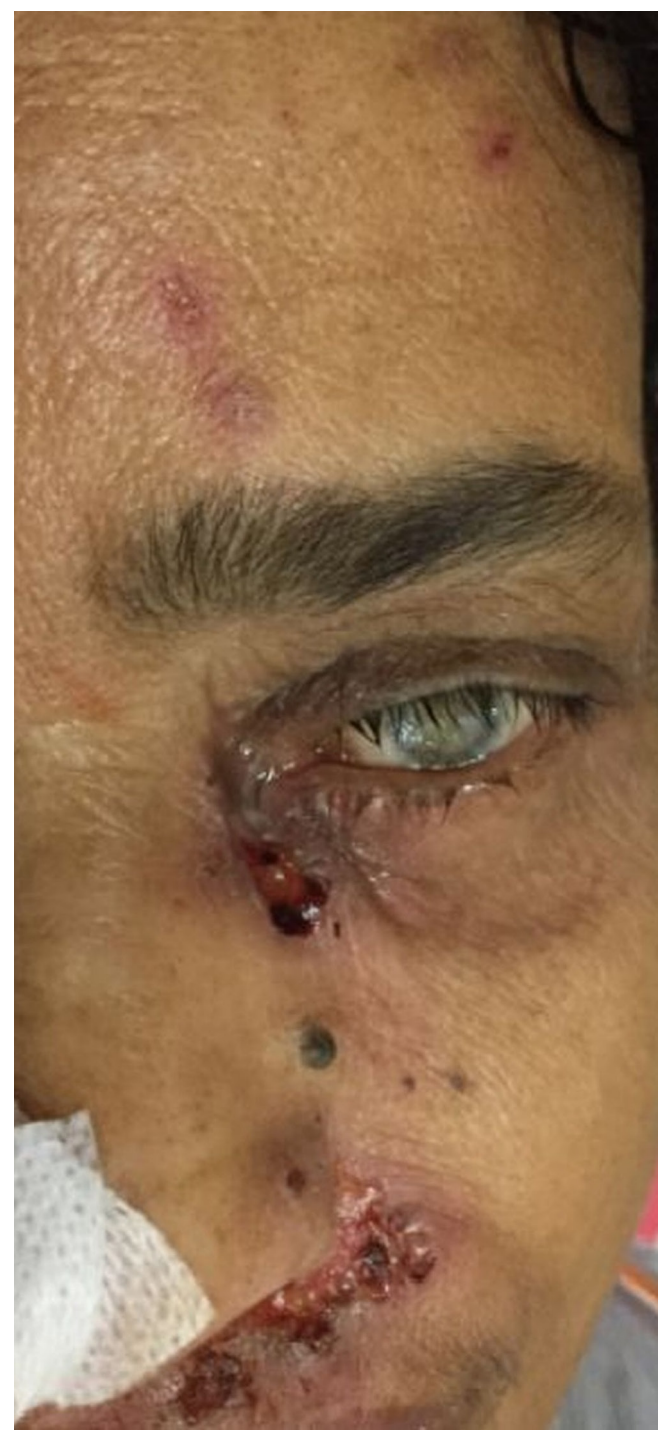

Figure 2 Left-sided facial ulceration and left eye keratosis.

self-manipulation because of these sensations. ${ }^{9}$ The diagnosis is made on the basis of the presence of facial paraesthesia, long history of repeated physical manipulation of the affected areas, facial ulceration with sparing of the nose tip and history suggestive of trigeminal nerve damage. ${ }^{10}$ The treatment of trigeminal trophic syndrome is often ineffective. Patients are counselled to avoid self-manipulation of the wound. Medications such as diazepam, amitriptyline, carbamazepine and chlorpromazine are used to reduce paraesthesia. ${ }^{11-13}$ Occlusive dressings may be applied over the affected area to reduce trauma. Transcutaneous electrical stimulation, stellate ganglionectomy, ipsilateral cervical sympathectomy, radiotherapy and iontophoresis with nerve blockade have been tried in treatment-resistant cases. 561415 Surgical reconstruction with skin grafting followed by pulsed radiofrequency has been tried to improve paraesthesias. ${ }^{91617}$ The differential diagnosis includes vasculitis (Wegener's granulomatosis, giant-cell arteritis, temporal arteritis), infections (varicella zoster, herpes simplex, leprosy, syphilis, leishmaniasis, cutaneous tuberculosis, blastomycosis, paracoccidioidomycosis), carcinoma (basal cell and squamous cell), destructive lethal midline granuloma, pyoderma gangrenosum and factitial dermatitis. ${ }^{9}$

\section{Learning points}

- Trigeminal trophic syndrome is a rare condition that occurs due to damage to the trigeminal nerve.

- It is characterised by persistent non-healing unilateral facial ulceration, typically involving the ala nasi with sparing of the tip of the nose.

- Anterior inferior cerebellar artery infarction is an uncommon cause of trigeminal trophic syndrome.

Contributors UK: review of literature and is the treating neurologist. RGM: concept, design, preparation and review of manuscript, and is the treating physician. AJ: review of literature and is the treating dermatologist. RNS: resident in charge.

Funding The authors have not declared a specific grant for this research from any funding agency in the public, commercial or not-for-profit sectors.

Competing interests None declared.

Patient consent Obtained.

Provenance and peer review Not commissioned; externally peer reviewed.

(C) BMJ Publishing Group Ltd (unless otherwise stated in the text of the article) 2018. All rights reserved. No commercial use is permitted unless otherwise expressly granted.

\section{REFERENCES}

1 Amarenco P, Hauw JJ. Anatomie des arteres cerebelleuses. Rev Neurol 1989;145:267-76.

2 Oas JG, Baloh RW. Vertigo and the anterior inferior cerebellar artery syndrome. Neurology 1992;42:2274-9.

3 Adams RD. Occlusion of the anterior inferior cerebellar artery. Arch Neurol Psychiatry 1943;49:765-70.

$4 \mathrm{Kim}$ HN, Kim YH, Park IY, et al. Variability of the surgical anatomy of the neurovascular complex of the cerebellopontine angle. Ann Otol Rhinol Laryngol 1990;99:288-96.

5 Loveman $A B$. An unusual dermatosis following section of the fifth cranial nerve. Arch Dermatol 1933;28:369-75.

6 McKenzie KG. Observations on the results of the operative treatment of trigeminal neuralgia. Can Med Assoc J 1933:29:492-6.

7 Mishra SN, Nayak CS, Deshpande DJ, et al. Trigeminal trophic syndrome: a rare entity. Indian J Dermato/ Venereol Leprol 2011;77:729.

8 Thomas J, Parimalam S, Selvi GT, et al. Trigeminal trophic syndrome in Hansen's disease. Int J Lepr Other Mycobact Dis 1991;59:478-80.

9 Sadeghi P, Papay FA, Vidimos AT. Trigeminal trophic syndrome--report of four cases and review of the literature. Dermato/ Surg 2004;30:807-12.

10 Kumar P, Thomas J. Trigeminal trophic syndrome. Indian J Dermatol 2014;59:75-6.

11 Finlay AY. Trigeminal trophic syndrome. Arch Dermatol 1979;115:1118.

12 Bhushan M, Parry EJ, Telfer NR. Trigeminal trophic syndrome: successful treatment with carbamazepine. Br J Dermatol 1999;141:758-9.

13 Kavanagh GM, Tidman MJ, McLaren KM, et al. The trigeminal trophic syndrome: an under-recognized complication. Clin Exp Dermatol 1996;21:299-301.

14 Westerhof W, Bos JD. Trigeminal trophic syndrome: a successful treatment with transcutaneous electrical stimulation. Br J Dermatol 1983;108:601-4.

15 Tada J, Ueda M, Abe Y, et al. Trigeminal trophic syndrome-a report of three patients. J Dermatol 1991;18:613-5.

16 Litschel R, Winkler $\mathrm{H}$, Dazert $\mathrm{S}$, et al. Herpes zoster-associated trigeminal trophic syndrome: a case report and review. Eur Arch Otorhinolaryngol 2003;260:86-90.

17 Goodnight JW, Calcaterra T. Trigeminal trophic syndrome: a report of two cases and review. Am J Otolaryngol 1994;15:219-22. 
Copyright 2018 BMJ Publishing Group. All rights reserved. For permission to reuse any of this content visit http://group.bmj.com/group/rights-licensing/permissions.

BMJ Case Report Fellows may re-use this article for personal use and teaching without any further permission.

Become a Fellow of BMJ Case Reports today and you can:

- Submit as many cases as you like

- Enjoy fast sympathetic peer review and rapid publication of accepted articles

Access all the published articles

- Re-use any of the published material for personal use and teaching without further permission

For information on Institutional Fellowships contact consortiasales@bmjgroup.com

Visit casereports.bmj.com for more articles like this and to become a Fellow 